\title{
Effects of matrine on the proliferation and apoptosis of vincristine-resistant retinoblastoma cells
}

\author{
BOWEN ZHAO ${ }^{1}$, BIN LI $^{2}$, QIAN LIU ${ }^{2}$, FEI GAO ${ }^{2}$, \\ ZHIBAO ZHANG ${ }^{2}$, HAIXIA BAI ${ }^{2}$ and YICHEN WANG ${ }^{2,3}$ \\ ${ }^{1}$ Beijing Tongren Hospital; ${ }^{2}$ Beijing Institute of Ophthalmology, Beijing Tongren Eye Center, Capital Medical University, \\ Beijing Ophthalmology and Visual Sciences Key Laboratory, Beijing 100005, P.R. China; \\ ${ }^{3}$ Department of Biological Sciences, University of Delaware, Newark, DE 19716, USA
}

Received February 19, 2019; Accepted January 22, 2020

DOI: $10.3892 /$ etm.2020.8992

\begin{abstract}
Matrine is an active component of Leguminosae plants and is thought to exhibit anti-tumor effects. However, the effects of matrine on drug-resistant cancer have not been fully elucidated. The present study aimed to investigate the effects of matrine on vincristine (VCR)-resistant retinoblastoma (RB) cells and to assess the underlying mechanisms governing this effect. The drug-resistant cell line SO-Rb50/VCR was established by incubation with VCR at increasing concentrations. The effects of matrine on SO-Rb50 and SO-RB50/VCR cell growth and proliferation were evaluated using light microscopy and Cell-Counting Kit- 8 assay. In addition, the effects of matrine on cell apoptosis, proliferation and cell cycle staging together with its potential underlying mechanisms were investigated. Matrine inhibited the proliferation of SO-Rb50 and SO-RB50/VCR cells in a concentration-dependent manner $(0.2-1.1 \mathrm{mg} / \mathrm{ml})$. However, matrine at the half-maximal inhibitory concentration $\left(\mathrm{IC}_{50}\right)$ appeared to trigger apoptosis of these cells and had a tendency to arrest the cell cycle at the G0/G1 phase. Matrine treatment also promoted the expression of Bax and reduced the expression of Bcl-2 and cyclin D1 compared with the control. However, matrine was not able to increase the sensitivity of cells to VCR. The results of the present study suggested that matrine has the potential to promote the apoptosis of SO-Rb50/VCR cells and arrest cell cycling, indicating a possible benefit of matrine for the treatment of drug-resistant RB.
\end{abstract}

Correspondence to: Professor Bin Li, Beijing Institute of Ophthalmology, Beijing Tongren Eye Center, Capital Medical University, Beijing Ophthalmology and Visual Sciences Key Laboratory, 17 Hougou Lane, Chongnei Street, Beijing 100005, P.R. China

E-mail: libin43_99@163.com

Key words: matrine, vincristine-resistant retinoblastoma, drug resistance, $\mathrm{SO}-\mathrm{Rb} 50$

\section{Introduction}

Retinoblastoma ( $R B$ ) is a malignant tumor of the retina and generally affects children under the age of 6 years, worldwide, with an incidence of 1:16,000-1:18,000 and $7,000-8,000$ new cases every year (1). RB is a threat to both the eyesight and life of children (2). Clinical treatments for RB include chemotherapy, radiotherapy, surgery, laser treatment and freezing (3-6). Among them, chemotherapy serves an important role in the management of $\mathrm{RB}$, and vincristine (VCR) is one the most commonly used chemotherapy drugs $(7,8)$. However, the inherent or acquired resistance of tumor cells to chemotherapeutic agents can lead to treatment failure (9-11).

The SO-Rb50 cell line is a human RB cell line. SO-Rb50 cells that are resistant to vincristine (SO-Rb50/VCR) can be established by maintaining the cells in increasing concentrations of vincristine over a period of nine months (12). $\mathrm{P}$-glycoprotein (P-gp) is an important protein that indicates multidrug resistance (13). It is of particular relevance to the treatment of RB to identify a compound that can effectively target SO-Rb50/VCR cells.

Matrine is a type of alkaloid found in Leguminosae plants, including Sophora flavescens Ait $(14,15)$. A number of studies have reported the beneficial effects of matrine on the quality of life and immune functions of patients with cancer $(16,17)$. Additionally, matrine has been reported to inhibit tumor cell proliferation through a variety of mechanisms, including inducing cancer cell differentiation and apoptosis, altering tumor cell cycle and inhibiting telomerase activity (18-21). Therefore, matrine may be a suitable compound for use in the treatment of a number of cancer types or cancer-related conditions. The present study demonstrated that matrine inhibited the proliferation of immortalized RB cells, decreased the rate of mitosis and increased apoptosis, which was also paralleled by corresponding changes in levels of the proteins regulating the cell cycle and apoptosis in the immortalized RB cells (22). However, to the best of our knowledge, the effects of matrine on VCR-resistant RB cells have not previously been reported. Therefore, the present study aimed to identify the various effects of matrine on $\mathrm{SO}-\mathrm{Rb} 50 / \mathrm{VCR}$ cells. 


\section{Materials and methods}

Establishment of drug-resistant cell lines. SO-RB50 cells were purchased from The Cell Bank of Type Culture Collection of the Chinese Academy of Sciences and cultured in DMEM (Gibco; Thermo Fisher Scientific, Inc.) supplemented with 10\% FBS (Hyclone; GE Healthcare Life Sciences) and 100 $\mathrm{U} / \mathrm{ml}$ penicillin-streptomycin (Sigma-Aldrich; Merck KGaA) in $5 \% \mathrm{CO}_{2}$ at $37^{\circ} \mathrm{C}$. Drug-resistance in SO-Rb50 cells was induced by stimulation with increasing concentrations of VCR (National Institutes for Food and Drug Control) at $37^{\circ} \mathrm{C}$, ranging from $75 \mu \mathrm{g} / 1$ to $600 \mu \mathrm{g} / 1$, over $\sim 9$ months, as previously described $(23,12)$. Cells receiving normal culture medium without any treatment were utilized as controls. The wells without cells and culture medium were used as blank controls.

Cell growth and proliferation. SO-Rb50/VCR cells were cultured in vitro as aforementioned, and the cell growth curve was measured after treatment with matrine at different concentrations. SO-Rb50/VCR cells $\left(3 \times 10^{3} / \mathrm{ml}\right)$ in the logarithmic growth phase were inoculated onto 96 -well plates (50 $\mu \mathrm{l} /$ well). The cells were incubated with matrine at different concentrations at $37^{\circ} \mathrm{C}(50 \mu 1,0.3,0.4,0.5,0.6,0.7,0.8,0.9,1,1.1$ and $1.3 \mathrm{mg} / \mathrm{ml}$ ). CCK-8 assay (Dojindo Molecular Technologies, Inc.) was used to analyze the cytotoxicity of matrine in accordance with the manufacturers protocol, and half-maximal inhibitory concentration $\left(\mathrm{IC}_{50}\right)$ was calculated. The optimal drug concentration (determined based on the $\mathrm{IC}_{50} ; 0.97 \mathrm{mg} / \mathrm{ml}$ ) was identified and selected for subsequent experiments.

Cell viability was calculated according to the following formula. Cell viability $(\%)=[(\mathrm{As}-\mathrm{Ab}) /(\mathrm{Ac}-\mathrm{Ab})] \mathrm{x} 100 \%$, in which 'As' is the absorbance of the experimental group, Ac is the absorbance of the control group (containing cell culture medium, CCK-8), Ab is the blank group (without cell and matrine solution culture medium, CCK-8). Inhibitory rate of cell proliferation $=100$-cell viability.

TUNEL assay. The level of cell apoptosis was evaluated before and after administration of matrine $\left(0.97 \mathrm{mg} / \mathrm{ml} ; \mathrm{IC}_{50}\right)$ for 0 , 12, 24 and $48 \mathrm{~h}$. The cells were collected, fixed in $4 \%$ paraformaldehyde at room temperature for $30 \mathrm{~min}$ and stained using TUNEL $\left(37^{\circ} \mathrm{C}\right.$ for $\left.5 \mathrm{~min}\right) /$ DAPI $(1 \mathrm{mg} / \mathrm{ml}$ for $5 \mathrm{~min})$. Subsequently, apoptosis was detected using flow cytometry (BD Biosciences) within $1 \mathrm{~h}$ and analyzed using FlowJo v7.6 software (FlowJo LLC).

Cell cycle analysis. The cultured SO-Rb50/VCR cells were treated with matrine $\left(0.97 \mathrm{mg} / \mathrm{ml}, \mathrm{IC}_{50}\right)$, and the cell cycle of cells without matrine treatment (control) and after treatment was assessed by flow cytometry (BD Biosciences) after PI (Merck KGaA) staining for 5 min protected from light at room temperature. The data were analyzed using FlowJo v7.6 software (FlowJo LLC).

Electron microscopic examination. To examine the cells using electron microscopy, the cells treated with matrine or vehicle were centrifuged $\left(1,000 \times \mathrm{g}\right.$ at $4^{\circ} \mathrm{C}$ for $\left.8 \mathrm{~min}\right)$, fixed with $3 \%$ glutaraldehyde at $4^{\circ} \mathrm{C}$ for $2 \mathrm{~h}$. For the preparation of ultra-thin sections $(1 \mu \mathrm{m})$, the cells were washed with phosphate-buffered saline, fixed with $1 \%$ osmic acid for $1 \mathrm{~h}$ at $4^{\circ} \mathrm{C}$, dehydrated with acetone and embedded in epoxide resin. After staining with uranyl acetate and lead citrate at room temperature for $5 \mathrm{~min}$, the sections were observed in at least least five fields under a transmission electron microscope (model no. EM208s; Koninklijke Philips N.V.). The images were processed using Image J (v150-win-jre6; National Institutes of Health).

Western blot analysis. Cultured SO-Rb50/VCR cells were treated with matrine $\left(0.97 \mathrm{mg} / \mathrm{ml} ; \mathrm{IC}_{50}\right)$ for $0,12,24$ and $48 \mathrm{~h}$ and protein was extracted from cell lines for western blot analysis using the triplePrep kit (cat. no. 28-9425-44; GE Healthcare Life Sciences). The 0 time point was set as control. Protein concentration was then determined using the bicinchoninic acid method. Protein ( $25 \mu \mathrm{g} /$ lane) was subsequently separated via $10 \%$ SDS-PAGE and transferred onto nitrocellulose membranes. Thereafter, the membranes were blocked in 5\% skimmed milk for $2 \mathrm{~h}$ at room temperature. The following antibodies were used for incubation for $24 \mathrm{~h}$ at $4^{\circ} \mathrm{C}$ : Bcl-2 (1:200; cat. no. ab117115, Abcam), Bax (1:200; cat. no. ab32503; Abcam) and $\beta$-actin (1:200; cat. no. ab179467; Abcam). Horseradish peroxidase (HRP)-conjugated goat anti-mouse IgG H\&L (1:100; cat. no. ab205719; Abcam) or HRP-conjugated goat anti-rabbit IgG H\&L (1:100; cat. no. ab6721; Abcam) were added and co-incubated for 1-2 h at room temperature. ECL Plus Western Blotting Reagent (cat. no. RPN2133; GE Healthcare Life Sciences) was added to the membrane. The bands were visualized utilizing a gel imaging system (Bio-Rad Laboratories, Inc.). Grey density was analyzed using Quantity One analysis software v1.4.6 (Bio-Rad Laboratories, Inc.).

Statistical analysis. The data are presented as mean \pm S.E.M ( $n=6$ in each group; analyses were performed in triplicate), and were analyzed using SPSS 17.0 (SPSS, Inc.). Significant differences between two groups were calculated by $t$-test. When three or more groups were compared, one-way ANOVA was applied to the data, followed by Tukey's post-hoc test. $\mathrm{P}<0.05$ was considered to indicate a statistically significant difference.

\section{Results}

Establishment and detection of drug-resistant cell lines. $\mathrm{SO}-\mathrm{Rb} 50$ cells grew in suspension with grape-like clusters, displaying large-size and uniform pattern. Following treatment with VCR, mass clusters of SO-Rb50 were disturbed and the cells presented mostly in the form of small clusters or single cells. The cell growth was significantly slower, and the cells became uneven in size following VCR treatment. However, the inhomogeneity of cell size became more obvious and there are more degenerative cells and cell debris after 4 to 6 days. A few cells lost their original shape and vacuolar structures appeared in the cytoplasm and the nuclear structure became unclear. These cells gradually increased with time, but there was no increase in the number of these cells during the following three weeks. After treatment for three weeks, the medium (with VCR) was washed away and replaced with fresh medium for further cell growth. The growth of SO-Rb50 cells was still slow at the beginning, but gradually recovered 
A

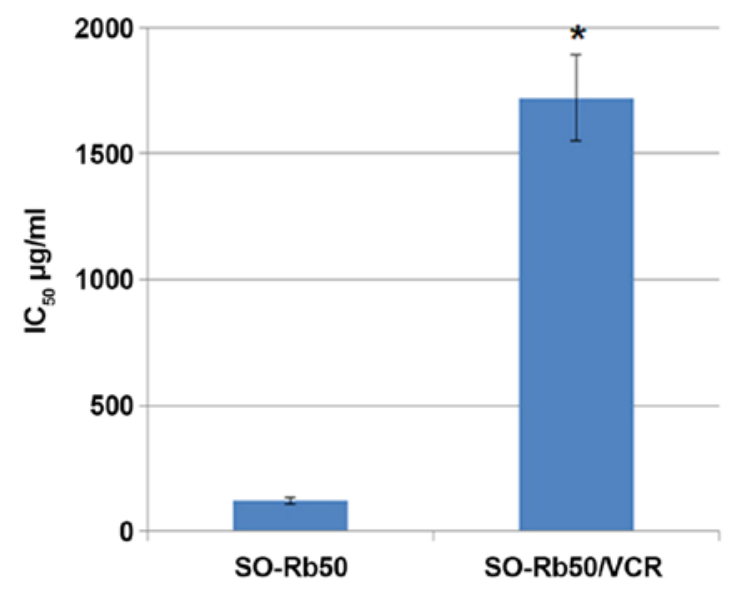

B
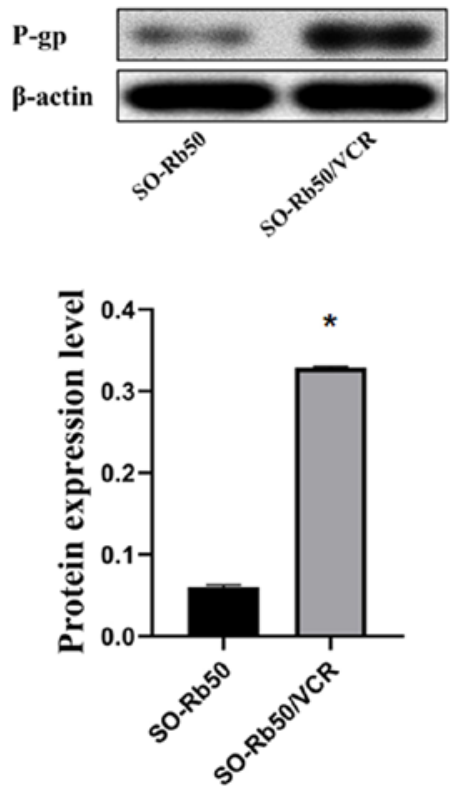

Figure 1. Features of SO-Rb50/VCR cells. (A) IC50 value of VCR in SO-Rb50 was significantly increased in SO-Rb50/VCR cells. (B) Western blot analysis was used to determine the expression levels of MDR1/P-gp protein. The level of MDR1/P-gp was increased in SO-Rb50/VCR cells compared with SO-Rb50 cells. "P<0.05 vs. SO-Rb50. $\mathrm{IC}_{50}$, half-maximal inhibitory concentration; MDR1/P-gp, multi-drug resistance protein 1/p-glycoprotein; SO-RB50/VCR, vincristine-resistant SO-RB50 cells; VCR, vincristine.
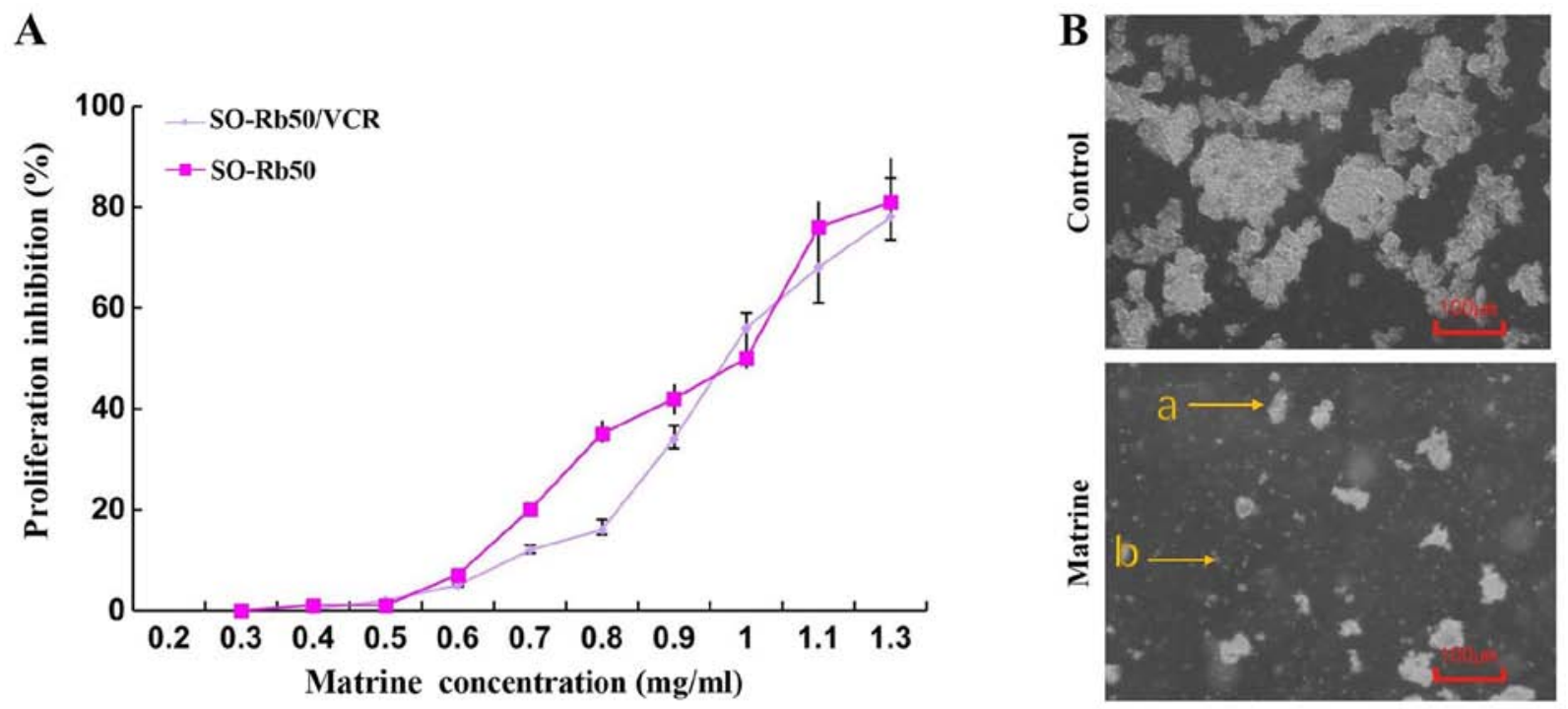

Figure 2. Matrine inhibits the proliferation of SO-RB50 and SO-RB50/VCR. (A) Proliferation inhibition curves of two RB cell lines treated with different concentrations of matrine for $24 \mathrm{~h}$. Matrine $(0.3-1.3 \mathrm{mg} / \mathrm{ml} ; 24 \mathrm{~h})$ exhibited significant suppressive effects on cellular growth of SO-Rb50 and SO-Rb50/VCR cells in a dose-dependent manner. The $\mathrm{IC}_{50}$ values of matrine on SO-Rb50 and SO-Rb50/VCR cells for $24 \mathrm{~h}$ were $0.96 \pm 0.04 \mathrm{mg} / \mathrm{ml} \mathrm{and} 0.97 \pm 0.08 \mathrm{mg} / \mathrm{ml}$, respectively. (B) Cell morphology before and after matrine treatment in SO-RB50/VCR cells. SO-Rb50/VCR cells grew as suspended aggregates in a uniform pattern with large nuclei and small cytoplasms. After treatment with matrine $\left(\mathrm{IC}_{50}\right)$ for $24 \mathrm{~h}$, the cell mass was reduced, uneven in size (a) and cytoplasmic debris (b) were observed. $\mathrm{IC}_{50}$, half-maximal inhibitory concentration; RB, retinoblastoma; SO-RB50/VCR, vincristine-resistant SO-RB50 cells; VCR, vincristine

over time (after $\sim 2-3$ weeks). At the same time, the abnormal morphology was gradually decreased or even disappeared; the cells were more uniform in size and the cell mass became larger. The above changes occurred again after increasing the concentration of drugs. SO-Rb50 cells could grow stably in the medium containing $600 \mathrm{~g} / \mathrm{ml}$ of VCR after an intermittent treatment with different concentrations (data not shown).

The $\mathrm{IC}_{50}$ values of $\mathrm{VCR}$ on SO-Rb50 and SO-Rb50/VCR cells for $48 \mathrm{~h}$ were $122 \pm 17.1 \mu \mathrm{g} / \mathrm{ml}$ and $1720 \pm 77.4 \mu \mathrm{g} / \mathrm{ml}$, respectively. The tolerance of SO-Rb50/VCR cells to VCR was $~ 14.1$ times higher than that of SO-Rb50 (Fig. 1A). P-gp protein expression was relatively low in untreated SO-Rb50 cells, but the level of P-gp protein increased significantly after an increase in VCR concentration (Fig. 1B).

Effect of matrine on cell proliferation. As indicated in Fig. $2 \mathrm{~A}$, matrine $(0.3-1.3 \mathrm{mg} / \mathrm{ml}$ over $24 \mathrm{~h})$ exhibited significantly suppressive effects on cellular growth of SO-Rb50 and 
A

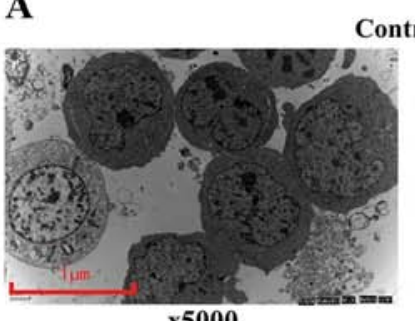

Control

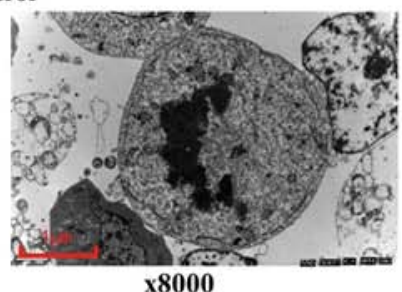

x8000

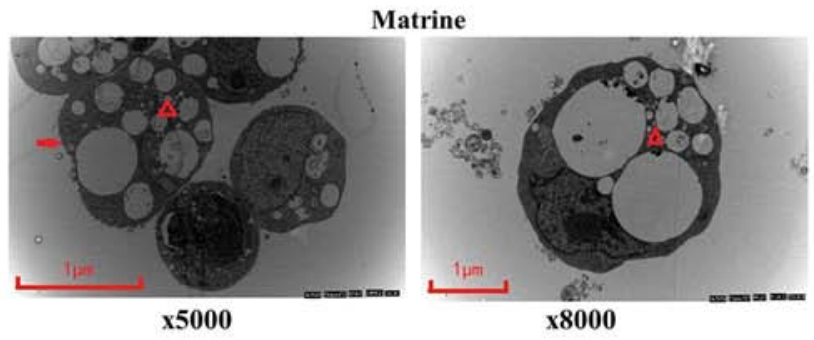

B
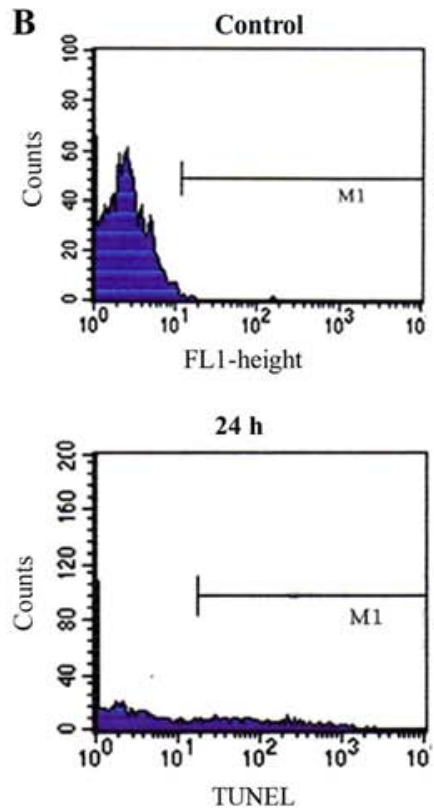

$12 \mathrm{~h}$

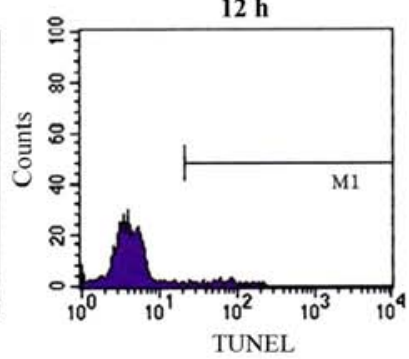

$48 \mathrm{~h}$

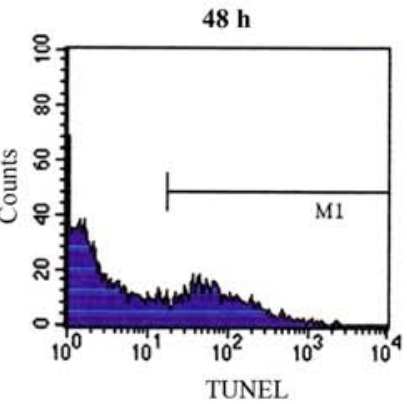

Figure 3. Matrine triggers apoptosis in SO-RB50/VCR cells. (A) Representative electron microscope images of cell morphology. The cells became uneven in size and cytoplasmic debris (arrow) and vacuolated cells (Triangle) were observed. (B) Apoptosis was detected using flow cytometry in cells treated with matrine for 0 (control), 12, 24 or 48 h. SO-RB50/VCR, vincristine-resistant SO-RB50 cells.
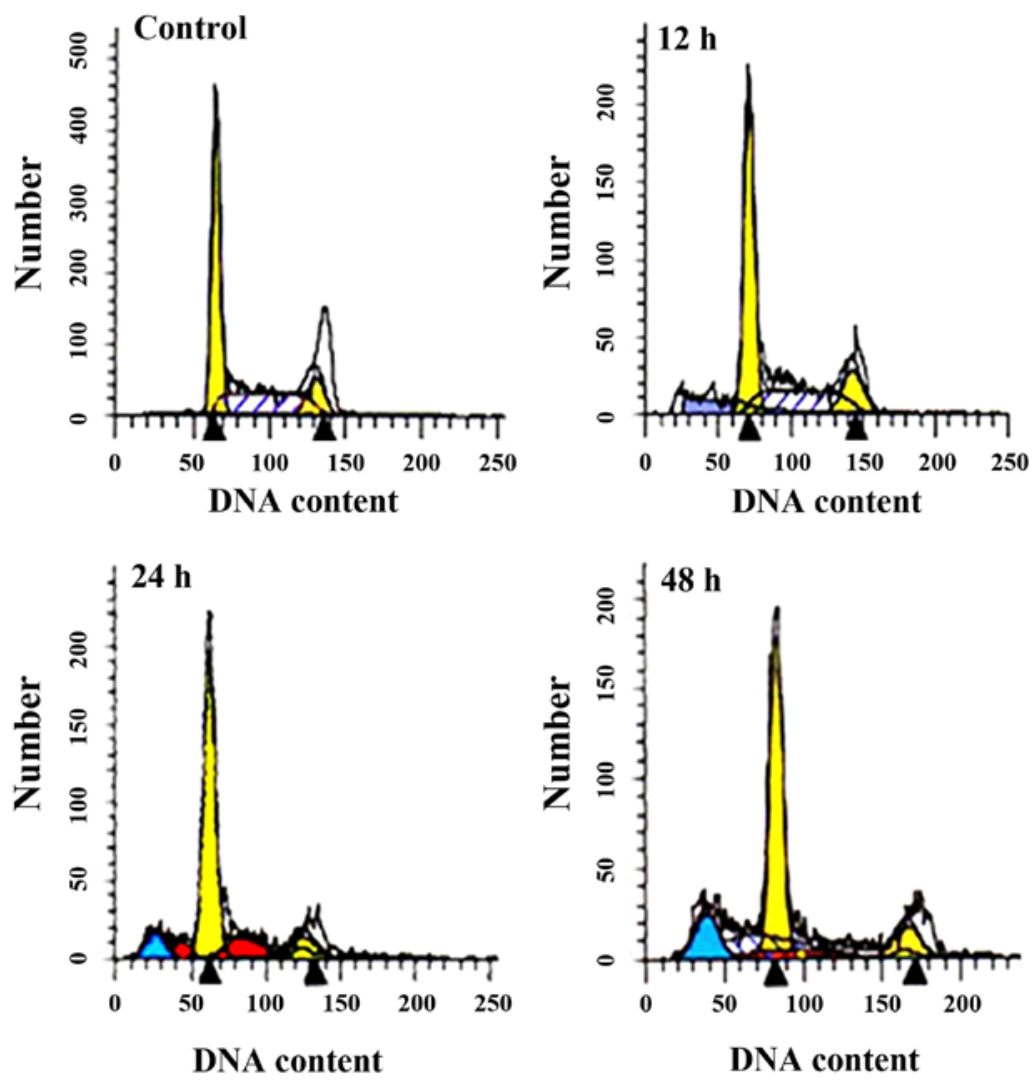

Figure 4. Matrine arrests the cell cycle at G0/G1 phase. After treatment with matrine for 0, 12, 24 and 48 h, cell cycle was arrested at G0/G1 phase. Arrows indicate cells at the $\mathrm{G} 1$ and $\mathrm{G} 2$ phase, respectively.

SO-Rb50/VCR cells in a dose-dependent manner, and the $\mathrm{IC}_{50}$ values of matrine on SO-Rb50 and SO-Rb50/VCR cells for $24 \mathrm{~h}$ were $0.96 \pm 0.04 \mathrm{mg} / \mathrm{ml}$ and $0.97 \pm 0.08 \mathrm{mg} / \mathrm{ml}$, respectively (Fig. 2A). There was no significant difference indicated in the proliferation-inhibition of matrine in SO-Rb50 and
SO-Rb50/VCR cells (Fig. 2A). SO-Rb50/VCR cells grew as suspended aggregates in a uniform pattern with large nuclei. After treatment with matrine $\left(\mathrm{IC}_{50}\right)$ for $24 \mathrm{~h}$, the cell mass was reduced, the cells became uneven in size and cytoplasmic debris and vacuolated cells were observed (Fig. 2B). 
A

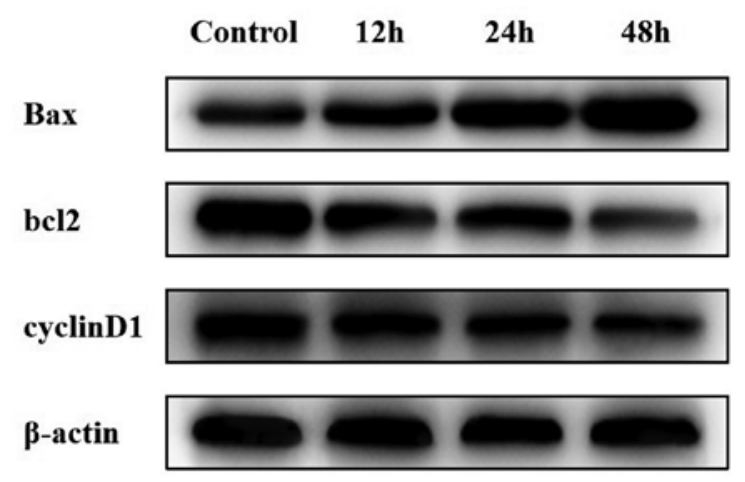

C

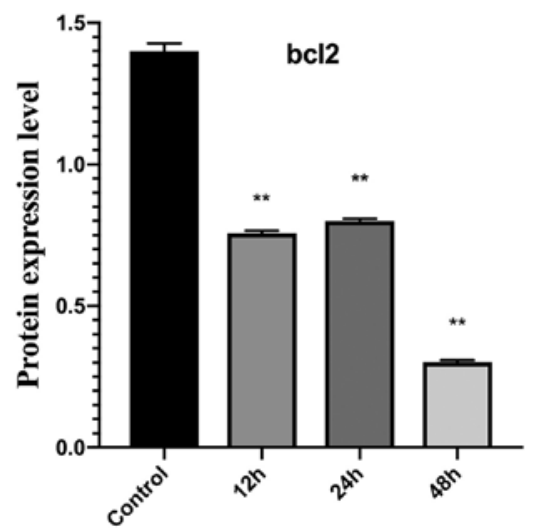

B

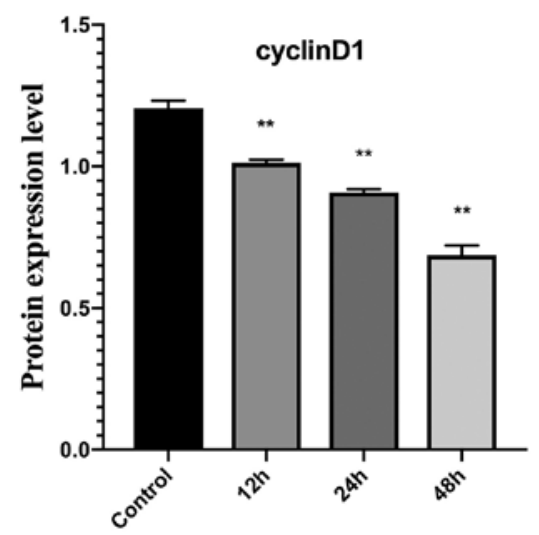

D

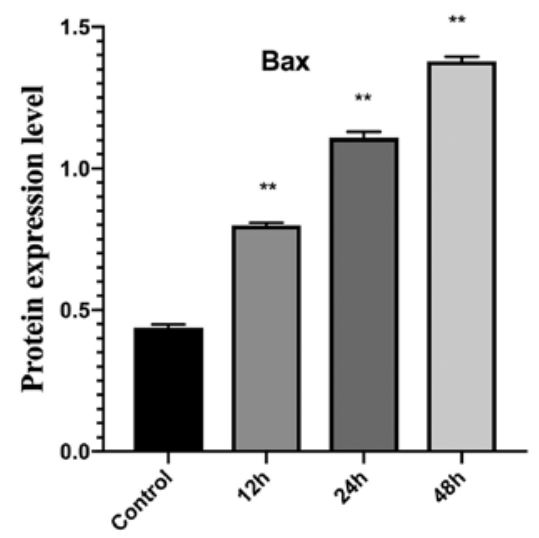

Figure 5. Matrine downregulates Bcl-2 expression and promotes Bax expression in SO-RB50/VCR cells. (A) Representative blots for Bax, Bcl-2 and cyclin D1. (B) Bax expression was promoted after matrine treatment for 0 (control), 12, 24 and $48 \mathrm{~h}$. (C) Bcl-2 expression was reduced after matrine treatment for 0 (control), 12, 24 and 48 h. (D) cyclinD1 expression was reduced after matrine treatment for 0 (control), 12, 24 and $48 \mathrm{~h}$. ${ }^{* *} \mathrm{P}<0.01$ vs. control.

Effect of matrine on apoptosis and the cell cycle. The ultrastructures of SO-Rb50/VCR cells in the control group and the matrine-treated group was observed using electron microscopy, and the cells exhibited significant degeneration, demonstrating features of apoptosis (chromatin condensation and vacuolar accumulation) after drug treatment compared with control group (Fig. 3A).

The results of a TUNEL assay indicated that the apoptosis rates of SO-Rb50/VCR cells in the control group and the matrine-treated (at $\mathrm{IC}_{50}$ concentration) group at 12, 24 and 48 were $0.13,3.2,20.2$ and $28.8 \%$, respectively (Fig. 3B).

In the control group, the cell cycle of SO-Rb50/VCR cells was $50 \pm 2.44 \%$ in the $\mathrm{G} 0 / \mathrm{G} 1$ phase, $28 \pm 2.4 \%$ in the $\mathrm{G} 2 / \mathrm{M}$ phase, and $32 \pm 2.41 \%$ in the S phase. After treatment with matrine, the proportion of cells in G0/G1 phase was elevated in a time-dependent manner between 12 and $48 \mathrm{~h}$. After treatment for $12 \mathrm{~h}$, the cells the proportions of cells were $54 \pm 3.77 \%$ in the $\mathrm{G} 0 / \mathrm{G} 1$ phase, $16 \pm 0.16 \%$ in the $\mathrm{G} 2 / \mathrm{M}$ phase and $30 \pm 1.76 \%$ in the $\mathrm{S}$ phase. Following treatment with matrine for $24 \mathrm{~h}$, cells were $68 \pm 4.13 \%$ in the $\mathrm{G} 0 / \mathrm{G} 1$ phase, $7 \pm 0.87 \%$ in the $\mathrm{G} 2 / \mathrm{M}$ phase and $22 \pm 1.4 \%$ in the $S$ phase. A period of $48 \mathrm{~h}$ after treatment, cells were $70 \pm 5.08 \%$ in the $\mathrm{G} 0 / \mathrm{G} 1$ phase, $7 \pm 0.65 \%$ in the G2/M phase and $19 \pm 0.89 \%$ in the S phase (Fig. 4).

Effect of matrine on Bax, Bcl-2 and cyclin D1 expression. Western blot analysis demonstrated that expression of Bcl-2 protein was significantly downregulated in the matrine-treated

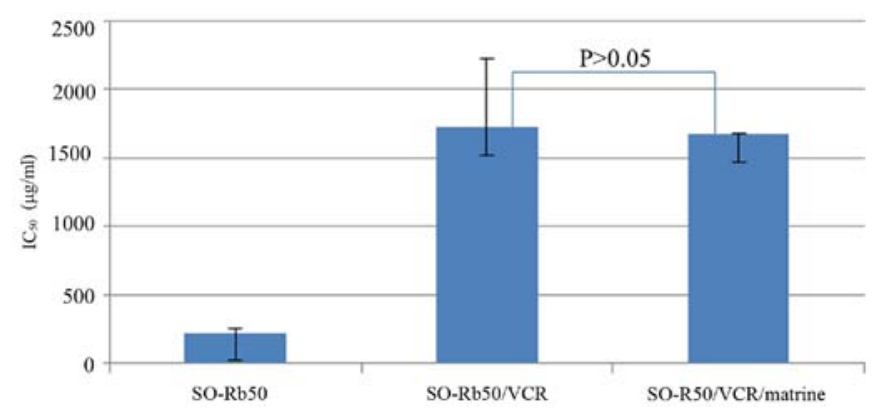

Figure 6. Matrine does not affect drug resistance of SO-Rb50/VCR cells to VCR. SO-RB50/VCR, vincristine-resistant SO-RB50 cells; VCR, vincristine.

group (at $\mathrm{IC}_{50}$ concentration) compared with the control group at 12,24 and $48 \mathrm{~h}$, whereas Bax protein was significantly upregulated at all time-points compared with the control (Fig. 5A-C).

The expression of Cyclin D1 was significantly downregulated after cells were treated with matrine for 12,24 and $48 \mathrm{~h}$, compared with the control group (Fig. 5D).

Effect of matrine on drug resistance of SO-Rb50/VCR cells. CCK-8 assay was performed to determine the reversal effect of matrine on drug resistance in SO-Rb50/VCR, the $\mathrm{IC}_{50}$ value of VCR of SO-Rb50/VCR cells treated with or without 
matrine for $24 \mathrm{~h}$ was $1720 \pm 77.4 \mu \mathrm{g} / \mathrm{ml}$ and $1670 \pm 103.6 \mu \mathrm{g} / \mathrm{ml}$, respectively, which indicated that matrine did not affect drug sensitivity after short-term treatment (Fig. 6).

\section{Discussion}

The treatment of retinoblastoma with chemotherapeutic drugs serves an important role in improved clinical outcomes for patients $(24,25)$. However, one of the biggest problems clinicians face is that patients are prone to drug resistance, leading to treatment failure $(26,27)$. In the present study, matrine treatment was indicated to reduce proliferation, induced apoptosis and arrested SO-Rb50/VCR cells cell cycle in the G0/G1 phase. However, matrine did not affect drug sensitivity after short-term treatment. These data suggest matrine may be a potential treatment for VCR-resistant retinoblastoma.

The results of the present study indicated that matrine reduces the proliferation rate of tumor cells $\mathrm{SO}-\mathrm{Rb} 50$ and SO-Rb50/VCR in a dose-dependent manner. The $\mathrm{IC}_{50}$ values of matrine in SO-Rb50 and SO-Rb50/VCR cells after $24 \mathrm{~h}$ were $0.96 \pm 0.04 \mathrm{mg} / \mathrm{ml}$ and $0.97 \pm 0.08 \mathrm{mg} / \mathrm{ml}$, respectively. The present study is in agreement with previous studies indicating the anticancer effects of matrine on liver cancer cells, leukemia cells and other tumor cells (28-31). This suggests that matrine treatment may exhibit broad antitumor activity, particularly against VCR-resistant tumor cells.

Apoptosis is not just a simple phenomenon of cell disintegration, but is also closely associated with the onset of a variety of diseases (32). Apoptosis is one of the main outcomes induced by different treatments on tumor cells $(33,34)$. The apoptosis induced by matrine occurred in a time-dependent manner. In the present study, the ultrastructures of RB cells were examined using transmission electron microscopy. Before treatment with matrine, SO-Rb50/VCR cells were characterized by a round or ellitical shape with a large nucleus and minimal cytoplasm. Karyokinesis and multinucleated cells were common. After treatment with matrine, apoptosis increased. The findings of the TUNEL assay further demonstrated that matrine treatment could markedly increase the apoptosis rate of SO-Rb50/VCR cells. The Bcl-2-related family of proteins constitutes an important class of either anti-apoptotic (e.g., Bcl-2, Bcl-XL) or pro-apoptotic gene products (including Bax and Bak) (35). $\mathrm{Bcl}-2$ directly or indirectly preserves the integrity of the outer mitochondrial membrane, thus promoting cellular survival (36). In contrast, the pro-apoptotic Bcl-2 family member Bax, promotes permeabilization and the release of cytochrome $\mathrm{C}$ and reactive oxygen species, which are important signals in the apoptosis cascade (37). In the present study, the apoptosis-associated protein Bcl-2 was downregulated and the Bax protein was upregulated in SO-Rb50/VCR cells after treatment with matrine.

In addition, the results of the present study showed that the presence of matrine exerted a function in cell cycle compared with control cells. The treated cells accumulated in the G0/G1 phase, and correspondingly, the percentage of cells in the $\mathrm{G} 2 / \mathrm{M}$ phase decreased compared with untreated cells. These results suggested that matrine could lead to a shorter DNA synthesis phase in SO-Rb50/VCR cells. This was partially confirmed by the result that matrine reduces the cyclin D1 content in treated cells compared to untreated cells. As a key regulator of cell cycle G1/S transition, cyclin D1 expression has previously been reported to be disturbed in a number of malignancies, due to gene amplification, chromosomal translocation, or mutations (38). It has been reported that tumor cells frequently display increased expression of cyclin D1 (39).

The effects of matrine on proliferation, apoptosis and cell cycle arrest of RB cells have been verified by several research groups (40-42). The present study demonstrated a novel function of matrine in treatment of SO-Rb50/VCR cells. Although specific mechanisms were not distinguished, the present study further supports the hypothesis that matrine has broad-spectrum anti-cancer activity. An additional finding of the present study was that matrine did not increase the sensitivity of cells to VCR. This finding differed from previous studies, in which matrine was shown to reverse resistance to paclitaxel (43), cisplatin and afatinib (44).

In summary, the results of the present study demonstrated that matrine promotes apoptosis of SO-Rb50/VCR cells and arrests the cell cycle. The present study revealed that matrine possesses this function not only in general RB cells but also in vincristine resistant $\mathrm{RB}$ cells.

\section{Acknowledgements}

Not applicable.

\section{Funding}

No funding was received.

\section{Availability of data and materials.}

The datasets used and/or analyzed during the present study are available from the corresponding author on reasonable request.

\section{Authors' contributions}

BZ, LC, BL, QL, FG, ZZ and HB performed the experiments and analyzed the data. BZ and YW designed the present study and wrote the manuscript.

\section{Ethics approval and consent to participate}

Not applicable.

\section{Patient consent for publication}

Not applicable

\section{Competing interests}

The authors declare that they have no competing interests.

\section{References}

1. Rao R and Honavar SG: Retinoblastoma. Indian J Pediatr 84: 937-944, 2017.

2. Steinmetz B, Hackl H, Slabáková E, Schwarzinger I, Smějová M, Spittler A, Arbesu I, Shehata M, Souček K and Wieser R: The oncogene EVI1 enhances transcriptional and biological responses of human myeloid cells to all-trans retinoic acid. Cell Cycle 13: 2931-2943, 2014. 
3. Zhan XX, Liu Y, Yang JF, Wang GY, Mu L, Zhang TS, Xie XL, Wang JH, Liu YM, Kong QF, et al: All-trans-retinoic acid ameliorates experimental allergic encephalomyelitis by affecting dendritic cell and monocyte development. Immunology 138: 333-345, 2013.

4. Philippeit C, Busch M and Dünker N: Epigenetic control of trefoil factor family (TFF) peptide expression in human retinoblastoma cell lines. Cell Physiol Biochem 34: 1001-1014, 2014.

5. Chawla B, Jain A and Azad R: Conservative treatment modalities in retinoblastoma. Indian J Ophthalmol 61: 479-485, 2013.

6. Abramson DH, Shields CL, Munier FL and Chantada GL: Treatment of retinoblastoma in 2015: Agreement and disagreement. JAMA Ophthalmol 133: 1341-1347, 2015.

7. Varan A, Kiratli H, Aydın B, Tarlan B, Poyraz CB, Akyüz C and Büyükpamukçu M: The treatment of retinoblastoma with four-drug regimen including cisplatin, etoposide, vincristine, and cyclophosphamide. Pediatr Hematol Oncol 29: 529-537, 2012.

8. Chantada $\mathrm{G}$ and Schaiquevich P: Intra-arterial Chemotherapy for Retinoblastoma. JAMA Ophthalmol 134: 1202-1203, 2016.

9. Lou Y, Qian W, Meng H, Mai W, Tong H, Tong Y, Huang J and Jin J: High efficacy of arsenic trioxide plus all-trans retinoic acid based induction and maintenance therapy in newly diagnosed acute promyelocytic leukemia. Leuk Res 37: 37-42, 2013.

10. Masetti R, Vendemini F, Zama D, Biagi C, Gasperini P and Pession A: All-trans retinoic acid in the treatment of pediatric acute promyelocytic leukemia. Expert Rev Anticancer Ther 12: 1191-1204, 2012.

11. Silverman JA and Deitcher SR: Marqibo ${ }^{\circledR}$ (vincristine sulfate liposome injection) improves the pharmacokinetics and pharmacodynamics of vincristine. Cancer Chemother Pharmacol 71: 555-564, 2013

12. Zhang H, Li B, Bai SW and Wang HJ: Constitutively active Akt contributes to vincristine resistance in human retinoblastoma cells. Cancer Invest 28: 156-165, 2010.

13. Ma X, Hu M, Wang H and Li J: Discovery of traditional Chinese medicine monomers and their synthetic intermediates, analogs or derivatives for battling P-gp-mediated multi-drug resistance. Eur J Med Chem 159: 381-392, 2018.

14. Liu Y, Xu Y, Ji W, Li X, Sun B, Gao Q and Su C: Anti-tumor activities of matrine and oxymatrine: Literature review. Tumour Biol 35: 5111-5119, 2014.

15. Yang N, Han F, Cui H, Huang J, Wang T, Zhou Y and Zhou J: Matrine suppresses proliferation and induces apoptosis in human cholangiocarcinoma cells through suppression of JAK2/STAT3 signaling. Pharmacol Rep 67: 388-393, 2015.

16. Chen J, Mei Q, Xu Y-C, Du J, Wei Y and Xu Z-M: Effects of matrine injection on T-lymphocyte subsets of patients with malignant tumor after gamma knife radiosurgery. J Chin Integr Med 4: 78-79, 2006 (In Chinese).

17. Huang S, Fan W, Liu P and Tian J: Meta analysis of compound matrine injection combined with cisplatin chemotherapy for advanced gastric cancer. Zhongguo Zhong Yao Za Zhi 36 (22): 3198-202, 2011 (In Chinese).

18. Zhang LP, Jiang JK, Tam JW, Zhang Y, Liu XS, Xu XR, Liu BZ and He YJ: Effects of Matrine on proliferation and differentiation in K-562 cells. Leuk Res 25: 793-800, 2001.

19. Jiang H, Hou C, Zhang S, Xie H, Zhou W, Jin Q, Cheng X, Qian R and Zhang X: Matrine upregulates the cell cycle protein E2F-1 and triggers apoptosis via the mitochondrial pathway in K562 cells. Eur J Pharmacol 559: 98-108, 2007.

20. Li H, Tan G, Jiang X, Qiao H, Pan S, Jiang H, Kanwar JR and Sun X: Therapeutic effects of matrine on primary and metastatic breast cancer. Am J Chin Med 38: 1115-1130, 2010.

21. Liu T, Song Y, Chen H, Pan S and Sun X: Matrine inhibits proliferation and induces apoptosis of pancreatic cancer cells in vitro and in vivo. Biol Pharm Bull 33: 1740-1745, 2010.

22. Zhao B, Li B, Bai S, Shen L, Ren R, Jonas JB, Xu X, Lu Q and Liu Q: Effects of matrine on proliferation and apoptosis of cultured retinoblastoma cells. Graefes Arch Clin Exp Ophthalmol 250: 897-905, 2012.

23. Wang XQ, Wang YC, Guo YT and Tang X: Effect of piperlongumine on drug resistance reversal in human retinoblastoma HXO-RB44/VCR and SO-Rb50/CBP cell lines. Int J Clin Exp Pathol 8: 2525-2534, 2015.

24. Shields CL, Ramasubramanian A, Thangappan A, et al: Chemoreduction for group $\mathrm{E}$ retinoblastoma: comparison of chemoreduction alone versus chemoreduction plus low-dose external radiotherapy in 76 eyes. Ophthalmology 116: 544-551 e541, 2009
25. Schueler AO, Anastassiou G, Jurklies C, Havers W, Wieland R and Bornfeld N: De novo intraocular retinoblastoma development after chemotherapy in patients with hereditary retinoblastoma. Retina 26: 425-431, 2006

26. Filho JP, Correa ZM, Odashiro AN, Coutinho AB, Martins MC, Erwenne CM and Burnier MN Jr: Histopathological features and P-glycoprotein expression in retinoblastoma. Invest Ophthalmol Vis Sci 46: 3478-3483, 2005.

27. O'Driscoll L, Walsh N, Larkin A, Ballot J, Ooi WS, Gullo G, O'Connor R, Clynes M, Crown J and Kennedy S: MDR1/ P-glycoprotein and MRP-1 drug efflux pumps in pancreatic carcinoma. Anticancer Res 27 (4B): 2115-2120, 2007.

28. Xu X, Ling Q, Gao F, He ZL, Xie HY and Zheng SS: Hepatoprotective effects of marine and kuhuang in liver transplant recipients. Am J Chin Med 37: 27-34, 2009.

29. Zhang S, Qi J, Sun L, Cheng B, Pan S, Zhou M and Sun X Matrine induces programmed cell death and regulates expression of relevant genes based on PCR array analysis in C6 glioma cells. Mol Biol Rep 36: 791-799, 2009.

30. Zhang Y, Zhang H, Yu P, Liu Q, Liu K, Duan H, Luan G, Yagasaki $\mathrm{K}$ and Zhang G: Effects of matrine against the growth of human lung cancer and hepatoma cells as well as lung cancer cell migration. Cytotechnology 59: 191-200, 2009.

31. Qin X-G, Hua Z, Shuang W, Wang YH and Cui YD: Effects of matrine on HepG2 cell proliferation and expression of tumor relevant proteins in vitro. Pharm Biol 48: 275-281, 2010.

32. Li J, Yang S and Zhu G: Postnatal calpain inhibition elicits cerebellar cell death and motor dysfunction. Oncotarget 8: 87997-88007, 2017.

33. Li Q, Cheng H, Zhu G, Yang L, Zhou A, Wang X, Fang N, Xia L, Su J, Wang M, et al: Gambogenic acid inhibits proliferation of A549 cells through apoptosis-inducing and cell cycle arresting. Biol Pharm Bull 33: 415-420, 2010.

34. Savill J and Fadok V: Corpse clearance defines the meaning of cell death. Nature 407: 784-788, 2000

35. Birkinshaw RW and Czabotar PE: The BCL-2 family of proteins and mitochondrial outer membrane permeabilisation. Semin Cell Dev Biol 72: 152-162, 2017.

36. Opferman JT and Kothari A: Anti-apoptotic BCL-2 family members in development. Cell Death Differ 25: 37-45, 2018.

37. Kim EM, Jung CH, Song JY, Park JK and Um HD: Pro-apoptotic Bax promotes mesenchymal-epithelial transition by binding to respiratory complex-I and antagonizing the malignant actions of pro-survival Bcl-2 proteins. Cancer Lett 424: 127-135, 2018.

38. Diehl JA and Knudsen KE: Splice variants and phosphorylated isoforms of cyclin D1 in tumorigenesis. In: D-type Cyclins and Cancer. Hinds PW, Brown NE (eds). Springer, Berlin, pp 91-109, 2018.

39. VanArsdale T, Boshoff C, Arndt KT and Abraham RT: Molecular pathways: Targeting the cyclin D-CDK4/6 axis for cancer treatment. Clin Cancer Res 21: 2905-2910, 2015.

40. Shao Q, Zhao X and Yao L: Matrine inhibits the growth of retinoblastoma cells (SO-Rb50) by decreasing proliferation and inducing apoptosis in a mitochondrial pathway. Mol Biol Rep 41: 3475-3480, 2014

41. Zhao B, Li B, Bai S, Shen L, Ren R, Jonas JB, Xu X, Lu Q and Liu Q: Effects of matrine on proliferation and apoptosis of cultured retinoblastoma cells. Graefes Arch Clin Exp Ophthalmol 250: 897-905, 2012.

42. Yu W, Li B, Ren RJ, Gao F, Li LQ, Liu XC and Wang Y: The effects of matrine on cell proliferation and telomerase activity in retinoblastoma cells in vitro. Zhonghua Yan Ke Za Zhi 42: 594-599, 2006 (In Chinese).

43. Luo SX, Deng WY, Wang XF, Lü HF, Han LL, Chen BB, Chen XB and Li N: Molecular mechanism of indirubin-3'-monoxime and Matrine in the reversal of paclitaxel resistance in NCI-H520/TAX25 cell line. Chin Med J (Engl) 126: 925-929, 2013.

44. Liao XZ, Tao LT, Liu JH, Gu YY, Xie J, Chen Y, Lin MG, Liu TL, Wang DM, Guo HY, et al: Matrine combined with cisplatin synergistically inhibited urothelial bladder cancer cells via down-regulating VEGF/PI3K/Akt signaling pathway. Cancer Cell Int 17: 124, 2017.

This work is licensed under a Creative Commons Attribution-NonCommercial-NoDerivatives 4.0 International (CC BY-NC-ND 4.0) License. 